Отримано: 18 квітня 2018 р.

Прорецеензовано: 23 квітня 2018 р.

Прийнято до друку: 04 травня 2018 р.

e-mail: pdziekan@interia.eu

DOI: 10.25264/2311-5149-2018-9(37)-86-91
Dziekański P. The information gap problem and the synthetic measure in the decisionmaking process of the organization. Наукові записки Наиіонального університету «Острозька академія». Серія «Економіка» : науковий журнал. Острог : Вид-во НаУОА, червень 2018. № 9(37). С. 86-91.

УДК: $332.122(1-77)$

Pawel Dziekański,

Ph. D., Institute of Law, Economics and Administration, Jan Kochanowski University in Kielce,

\title{
THE INFORMATION GAP PROBLEM AND THE SYNTHETIC MEASURE IN THE DECISION-MAKING PROCESS OF THE ORGANIZATION
}

The development of the global information society means that information is treated as an economic good, a basic resource and a basic economic category. The subject of the article is internal diversification and assessment of the commune's competitiveness in the aspect of regional differentiation of the financial situation on the example of synthetic evaluation of the Swiętokrzyskie voivodeship communes. Synthetic measures based on a non-standard method and distance in real space with the Euclidean metric were used to achieve this goal. The value of the measure ranged from 0.28 (Tartów, the weakest unit) to 0.69 (Ożarów, the best unit) in 2010 and from 0.35 (Imielno, the weakest) to 0.70 (Polaniec; the best) in 2015 for the non-standard method. In the case of a measure based on the distance in real space with the Euclidean Meter from 0.35 (Ożarów, best) to 0.77 (Dwikozy, the weakest) in 2010 and from 0.36 (Polaniec; best) to 0.70 (Imielno the weakest) in 2015.

Key words: region, commune, financial situation, synthetic measure.

\author{
Джєканьський Павел, \\ доктор філософії \\ Інститут права, економіки і управління, Університет ім. Яна Кохановського у Кєльце,
}

\section{ПРОБЛЕМА ІНФОРМАЦЙНОГО РОЗРИВУ І СИНТЕТИЧНОГО ПОКАЗНИКА У ПРОЦЕСІ ПРИЙНЯТТЯ РІШЕНЬ В ОРГАНІЗАЦІЇ}

Розвиток глобального інформачійного суспільства означає, щцо інформаџію розглядають як економічний товар, основний ресурс і основну економічну категорію. Предметом иієєї статті є внутрішня диверсифікація й оиінка конкурентоспроможності громади в розрізі регіональних відмінностей у фінансовому становищі на прикладі синтетичної оцінки общин Швєнтокшиського Воєводства. Для досягнення иієї мети було використано синтетичні показники на основі застосування нестандартного методу та відстані в реальному просторі разом з евклідовою метрикою. Значення показника коливається від 0,28 (Тарлув, найслабща одиниия) до 0,69 (Ожарув, найкраща одиниия) у 2010 роиі, а також від 0,35 (Імєльно, найслабша община) до 0,70 (Пованещь, найкраща) у 2015 році з використанням нестандартного методу. У випадку вимірювання на основі відстані в реальному просторі за допомогою евклідоміра - від 0,35 (Ожарув, найкраще) до 0,77 (Двікози, найслабше) у 2010 рощі, а також від 0,36 (Пованець, найкраще) до 0,77 (Імєльно, найслабще) у 2015 роиі.

Ключові слова: регіон, громада, фінансова ситуачія, синтетичний показник.

\section{Intoduction.}

The development of the global information society means that information is treated as an economic good (a free good, a product, a good, an element of the infrastructure of the economy), a basic resource and a basic economic category. In the modern economy, apart from the three classic capitals: land, capital and human labor, it is treated as the fourth factor of production (Pomykalski, 2001). Excess information forces the recipient to make an effort in the process of their reception, selection and analysis. The ability to manage information is becoming increasingly important (Materska, 2004, 3-11; Dziekański, 2012, 387-403). Information as an organizational asset allows to gain an advantage over competitors. Good information, i.e. characterized by a certain set of features, such as availability, timeliness, reliability, completeness, comparability or processability, is undoubtedly one of the most valuable assets of a given business entity (Oleński, 1997, 14-15).

The theory of economics has always had problems with defining the public sector, the rules of its functioning or presenting goals and tasks that it has to implement in the field of administrative and institutional structure (Kleer 2005, 9). On the national scale there is a lack of information to help local authorities to make a real assessment of the situation and analysis of economic trends and their social effects, which would allow the preparation of appropriate programs and strategic actions (Sobczyk 2009, 137-149).

An effective way of managing the local government is to use the limited resources to effectively carry out tasks that are supposed to be a response to the needs of society. The basic tool used to allocate funds, and thus 
allowing the implementation of these tasks, is the budget of local government units (Sekuła 2015, 229-238). Communes include public matters of local importance and the poviat performs public tasks of a supra-municipal nature. It has the right to enact local law acts in the area of the commune.

\section{Method and aim of research}

To analyze complex phenomena, it is necessary to consider many variables. Synthetic measures are used to evaluate the complex phenomena (Zeliaś 1997). The aim of the study was to assess and recognize the spatial diversity of the financial situation of the southern communes of the ŚwiętokrzyskieVoivodeship. Data for 58 communes (the region for which agriculture is characteristic), which come from the Local Data Bank - the Central Statistical Office, were used for the calculations.

A set of variables describing the financial situation

\begin{tabular}{|l|l|c|c|l|l|l|}
\hline & indicators per capita & & & budgetindicators & \\
\hline X1. & own income minus PIT minus CIT & S & X9. & share of own income minus PIT minus CIT in total income & S \\
\hline X2. & income from PIT and CIT & S & X10. & share of operating surplus in total income & S \\
\hline X3. & income from taxes and local fees & S & X11. & share of own revenues in total revenues & S \\
\hline X4. & operatingsurplus & S & X12. & share of subsidies in total revenues & D \\
\hline X5. & propertyexpenses & S & X13. & share of subsidies in total revenues & D \\
\hline X6. & currentexpenses & D & X14. & share of capital expenditures in total expenditure & S \\
\hline X7. & interestexpenses & D & X15. & share of current expenditures in total expenditure & D \\
\hline X8. & localdebt & D & X16. & self-financingrate & S \\
\hline
\end{tabular}

$\mathrm{S}$ - stimulant; D - destimulant.

Source: study based on Indicators for the assessment of the financial condition of local government units in 2012-2014, Ministry of Finance, Warsaw 2015.

While selecting diagnostic variables, both substantive and statistical premises were applied, ie. analysis of diagonal elements of the inverse matrix to the correlation matrix R (diagonal elements of the R-1 matrix did not exceed 10) and the coefficient of variation (for particular features greater than $10 \%$ ).

Diagnostic variables usually have different titers and different ranges of variation, which makes it impossible to compare them directly. A procedure of normalization of diagnostic variables was carried out using the zero uni disillusion method. Stimulants were neutralized according to the formula:

$$
\begin{gathered}
z_{i j}=\frac{x_{i j}-\min _{i} x_{i}}{\max _{i} x_{i}-\min _{i} x_{i}} \\
\text { whiledestimulant: } \\
z_{i j}=\frac{\max _{i}-x_{i j}}{\max _{i} x_{i}-\min _{i} x_{i}}
\end{gathered}
$$

where: $\mathrm{i}=1,2, \ldots \mathrm{N} ; \mathrm{j}=1,2, \ldots, \mathrm{p}$ ( $\mathrm{N}$ is the number of objects (communes), and $\mathrm{p}$ - the number of features); - means the value of the neutralizing feature for the tested unit, $x i j-$ means the value of the $\mathrm{j}^{\text {th }}$ characteristic for the tested unit, max - the maximum value of the $j^{\text {th }}$ feature, min - the minimum value of the $j^{\text {th }}$ feature (Tokarski 2005; Wysocki, Lira 2005).

Next, the synthetic measure of the financial situation was calculated ${ }^{1}$ based on the distance in real space with the Euclidean metric (first method) according to the formula:

$$
S E_{i t}=\sqrt{\frac{\sum_{j=1}^{p}\left(1-z_{i j t}\right)^{2}}{p}}
$$

Synthetic measure (3) measures reduced to the range $[0 ; 1]$. The higher the value of this indicator, the worse the financial situation of the commune.

The second method of constructing a synthetic measure is based on the method without a model, using the formula:

$$
S_{i}=\frac{1}{p} \sum_{j=1}^{p} z_{i j}(i=1,2, \ldots, p)
$$

where: $\mathrm{si}$ - a synthetic measure in the analyzed period, zij - features of the synthetic index structure, $\mathrm{p}$ - the number of features. The indicator assumes a value between $[0,1]$. A value closer to unity means that the object is

${ }^{1}$ Separately for indicators per capita and for budget indicators; finally creating the average of both measures. 
characterized by a high level of the analyzed phenomenon, while when the values are closer to 0 - the object is less developed under the examined factor (Dziekański 2014, 98-108, Dziekański 2015, 261-279).

The examined objects were divided into 4 typological groups according to the quartile values. The value of the synthetic measure was also verified based on the correlation coefficient among others Sperman's, t-Kendall's (Dziekański 2016, pp. 79-91, Trojak, Tokarski 2013, Mioduchowska-Jaroszewicz 2013, 127-140).

Competitiveness and the financialsituation of the commune and the problem of information in the decision-makingprocess

Territorial competitiveness is achieved through policies aimed at promoting local economic development. It is implemented by the context of the implementation of tasks of technical infrastructure, social and spatial and ecological order, as well as public order and safety. A comprehensive approach to assessing the competitiveness of the region should be aimed at using the internal potential of areas (Wais 2014). The choice of specificvariablesdescribingcompetitivenessmay be based, for example, on the model 4 of the region'scapitals (Gorzelak, Płoszaj, Smętowski 2006, 67-82) orelements of the region'sbalancesheetbuilt by social, economic, ecological and spatial order.

The assessment of the financial situation allows obtaining information on sources of financing local government activities, directions of its development or the use of public cash resources and fulfillment of duties towards the local community (Filipiak, 2006, 138-143). It allows to define not only the efficiency of these units' functioning, i.e. the ability to meet their obligations, but also the possibility of increasing the quality standard of services provided by them to local communities (Dziekański 2014, Pawlik 2011, Satoła 2015, 115-123). The basic sources of financing tasks carried out by local government units are own revenues, targeted subsidies and subsidies. The first ones prove the foresight of management boards and economic activity of residents and their state of ownership. The second one illustrates the aspirations of the communes to increase their possessions, contributing to the improvement of the living conditions of the inhabitants and to the general social and economic development (Sobczyk 2009, 137-149).

Information is one of the basic resources of every organization. Public sector institutions are increasingly turning to IT solutions - in the field of information management, which allows the collection, updating and use of data collected within the organization. Information is an important resource as the classic factors of production, which include: labor, land and capital. It decides about the successes or failures of implemented projects, is the source of power, influence. Fully valuable information can be considered as a strategic resource enabling to achieve and maintain a proper position, even in the conditions of a very strong competitive fight between organizations (Piecuch, 2013, 161-170). Statistical data, activity reports or general reports constitute a group of information held by public sector institutions. These data sources contain a huge amount of information, often in unstructured form, which further hinders the search process (Krawczyk, 2011, 141-147). Information describes events or phenomena and constitutes a data set. It becomes an element of knowledge in three cases: when it is compared with another, when the consequences of a given information are the basis for decisions and actions and when one information is combined with another (Lewandowski, 2002,142). Organizationsshouldoffercustomers not only the right products, but alsoinformation (Nowicka-Skowron, 2000, 63).

Having the right information at the right time is much more valuable than any large capital. It is important to maintain and provide information to users as well as technical and organizational means of data collection, communication, processing and their protection. Globalization of the market, increased competition, focus on quality in order to gain market advantage and changes in the internal and external environment of enterprises force effective management of information resources (Frąś, 2011).

According to J. Oleński, information, information processes and information systems in politics, economy and social life have always played an important role. It co-decides about the course of real, material, economic and political social processes. Information becomes a determinant in the society and economy of the level of economic and social development as well as its directions and dynamics (Oleński, 2000, 21). The information fulfills a special role in the processes of management, and decision making, because their essence is the collection, processing and transfer of information (Oleński, 1997, 15).

J. Kisielnicki and H. Sroka, believe that the basis for the functioning of any organization is the possession of specific information that constitutes its resources. It is the kind of resourcesthatallowsus to increaseourknowledgeaboutus and the worldaroundus (Kisielnicki, Sroka, 1999, 13).

The information society being formed treats information as a key resource or commodity, the value of which depends on the speed of transfer and management efficiency. The determinant of collecting and selecting information is ensuring its appropriate value. The value of information depends on the following factors (Griffin, 2004; Stoner, Wankel, 1996): quality, accuracy, compliance with facts, quantity and completeness (Wiatrak, 1997, 33-42). 


\section{Synthetic measure of the financial situation}

The competitiveness of the studied communes in the ŚwiętokrzyskieVoivodeship is difficult, as indicated by the low values of the synthetic measure. Its value ranged from 0.28 (Tarłów, the weakest unit) to 0.69 (Ożarów, the best unit) in 2010 and from 0.35 (Imielno, the weakest) to 0.70 (Połaniec; the best) in 2015 in case. In the case of a measure from 0.35 (Ożarów, the best) to 0.77 (Dwikozy, the weakest) in 2010 and from 0.36 (Połaniec, the best) to 0.70 (Imielno, the weakest) in 2015 (table 1).

Table 1

The level of synthetic development indicator for rural communes in the ŚwiętokrzyskieVoivodeship $(2010,2015)$

\begin{tabular}{|c|c|c|c|c|}
\hline & \multicolumn{2}{|c|}{$S_{i}$} & \multicolumn{2}{|c|}{$\mathbf{S E}_{\text {it }}$} \\
\hline & 2010 & 2015 & 2010 & 2015 \\
\hline $\begin{array}{c}\text { A } \\
\text { Verygood }\end{array}$ & $\begin{array}{c}\text { Ożarów (3)0,69 } \\
\text { Tuczępy (2)0,62 } \\
\text { Bogoria (2)0,59 } \\
15 \text { / 0,57 }\end{array}$ & $\begin{array}{l}\text { Połaniec (3)0,70 } \\
\text { Ożarów (3)0,65 } \\
\text { Kije (2) } 0,60 \\
15 / 0,55 \\
\end{array}$ & $\begin{array}{c}\text { Ożarów (3)0,35 } \\
\text { Tuczępy (2)0,42 } \\
\text { Rytwiany (2)0,47 } \\
15 \text { / 0,50 } \\
\end{array}$ & $\begin{array}{c}\text { Połaniec (3)0,36 } \\
\text { Ożarów (3)0,39 } \\
\text { Kije (2) } 0,45 \\
15 / 0,51\end{array}$ \\
\hline $\begin{array}{c}\text { B } \\
\text { good }\end{array}$ & $\begin{array}{c}\text { Wodzisław (2)0,52 } \\
\text { Moskorzew (2)0,52 } \\
\text { Włoszczowa (3)0,51 } \\
14 \text { / 0,49 } \\
\end{array}$ & $\begin{array}{c}\text { Stopnica (3)0,48 } \\
\text { Nagłowice (2)0,48 } \\
\text { Krasocin (2)0,48 } \\
14 \text { / 0, } 47 \\
\end{array}$ & $\begin{array}{c}\text { Działoszyce (3) } 0,54 \\
\text { Szydłów (2) } 0,55 \\
\text { Stopnica (3) } 0,55 \\
14 / 0,57 \\
\end{array}$ & $\begin{array}{c}\text { Sędziszów (3)0,57 } \\
\text { Stopnica (3)0,57 } \\
\text { Obrazów (2)0,57 } \\
14 \text { / 0,58 } \\
\end{array}$ \\
\hline $\begin{array}{c}\mathrm{C} \\
\text { poor }\end{array}$ & $\begin{array}{c}\text { Iwaniska (2) } 0,47 \\
\text { Złota (2) } 0,47 \\
\text { Oleśnica (2)0,47 } \\
14 \text { / 0,44 }\end{array}$ & $\begin{array}{c}\text { Opatowiec (2)0,44 } \\
\text { Kluczewsko (2)0,44 } \\
\text { Wodzisław (2)0,44 } \\
14 \text { / 0,42 }\end{array}$ & $\begin{array}{c}\text { Oksa (2) 0,59 } \\
\text { Stupia (2)0,59 } \\
\text { Oleśnica (2)0,60 } \\
14 / 0,62 \\
\end{array}$ & $\begin{array}{c}\text { Wodzisław (2)0,61 } \\
\text { Opatowiec (2)0,61 } \\
\text { Wilczyce (2)0,61 } \\
14 \text { / 0,63 }\end{array}$ \\
\hline $\begin{array}{c}\mathrm{D} \\
\text { bad }\end{array}$ & $\begin{array}{c}\text { Wojciechowice (2)0,40 } \\
\text { Opatów (3) 0,40 } \\
\text { Pacanów (2)0,40 } \\
15 / 0,37\end{array}$ & $\begin{array}{c}\text { Radków (2) } 0,41 \\
\text { Sobków (2)0,40 } \\
\text { Dwikozy (2)0,40 } \\
15 \text { / 0,39 }\end{array}$ & $\begin{array}{c}\text { Pacanów (2)0,65 } \\
\text { Samborzec (2)0,66 } \\
\text { Wojciechowice (2)0,66 } \\
15 / 0,70\end{array}$ & $\begin{array}{c}\text { Klimontów (2)0,65 } \\
\text { Słupia (2) 0,65 } \\
\text { Sobków (2)0,65 } \\
15 \text { / 0,67 }\end{array}$ \\
\hline \multicolumn{5}{|c|}{ Differentiation of syntheticmeasure } \\
\hline $\min$ & Tarłów 0,28 & Imielno 0,35 & Dwikozy 0,77 & Imielno 0,70 \\
\hline $\max$ & Ożarów 0,69 & Połaniec 0,70 & Ożarów 0,35 & Połaniec 0,36 \\
\hline Standard deviation & 0,08 & 0,07 & 0,08 & 0,07 \\
\hline gap & 0,41 & 0,36 & 0,42 & 0,34 \\
\hline Quartered gap & 0,13 & 0,08 & 0,11 & 0,08 \\
\hline $\begin{array}{c}\text { coefficient of } \\
\text { variation }\end{array}$ & 0,18 & 0,15 & 0,14 & 0,12 \\
\hline
\end{tabular}

$S_{i}$ synthetic measure acc. non-standard methods; $S E_{i t}$ a synthetic measure based on the distance in real space with the Euclidean metric; due to the volume of the study, Table 3 shows the best units in the group, the number of units and the average value of the measure of the synthetic group.

Source: own study based on CSO BDL data.

In order to assess the differences in the level of financial condition in the analyzed years and determine whether these differences have increased or changed, the use of, among others, analysis of standard deviations and range as well as minimum and maximum value of the measure.

In 2015, compared to 2010, the difference in competitiveness decreased (expressed in absolute terms, 0.080.07 for $S_{i}$ i $S E_{i}$ ), this also confirms the value of the range, which was lower in 2015 than in 2010 - from 0.41 to $0.36-S_{i} ;$ z 0,42 do $0,34-S E_{i t}$. This can be interpreted as a deterioration of competitiveness over the analyzed years.

Figure 1 presents correlograms describing the relationship between taxonomic changes in competitiveness measures and their level. Measures presented in Table 5 indicate high consistency of the obtained results with selected methods. The conclusion is that measures of competitiveness $S_{i}-S E_{i t}$ in years 2010-2014 they were subject to divergence (Pearson's correlation coefficients between $S_{i}-S E_{i t}$ was $-0,983$ and $-0,992$; for $S_{i}-d S_{i}$ was 0,627 and 0,345 ; for $S E_{i t}-d S E_{i t}$ was $\left.0,518-0,464\right)$. This may indicate that each of the analyzed measures indicates a similar classification of the level of security in terms of competitiveness, and their spatial differentiation was quite stable. 
Figure 1. Relation of the synthetic measure - change dynamics
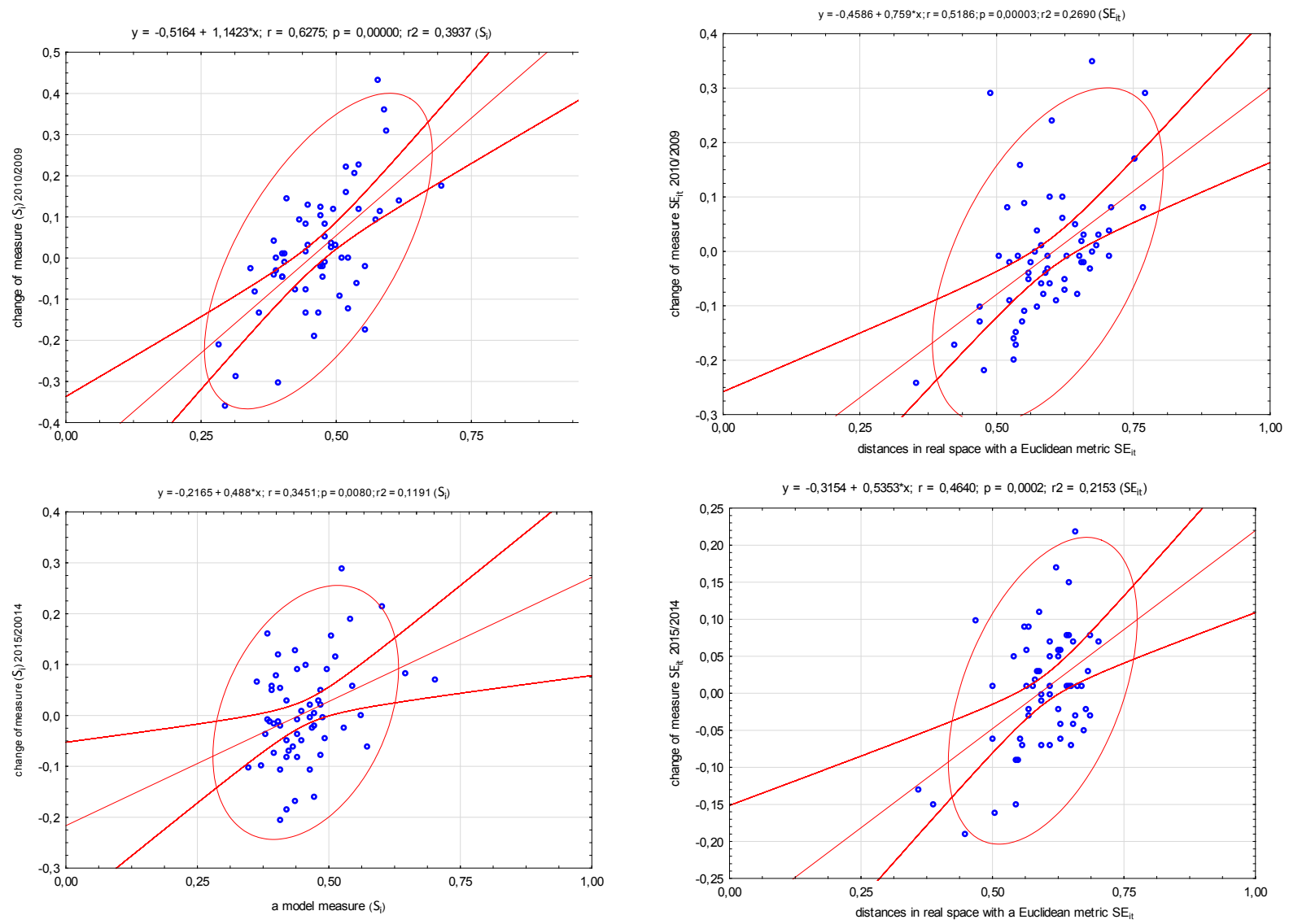

Source: own study based on CSO BDL data.

Table 3

Value of the correlation of the taxonomic measure and its changes

\begin{tabular}{|c|c|c|c|c|c|}
\hline \multicolumn{2}{|c|}{} & Pearson & R Spearman & Tau Kendalla & Gamma \\
\hline Relation & 2010 & $-0,983$ & $-0,983$ & $-0,907$ & $-0,904$ \\
\cline { 2 - 6 }$S_{i}-S E_{i t}$ & 2015 & $-0,992$ & $-0,988$ & $-0,934$ & $-0,930$ \\
\hline Relation & 2010 & 0,627 & 0,554 & 0,398 & 0,397 \\
\cline { 2 - 6 }$S_{i}-d S_{i}$ & 2015 & 0,345 & 0,282 & 0,198 & 0,198 \\
\hline Relation & 2010 & 0,518 & 0,528 & 0,409 & 0,404 \\
\cline { 2 - 6 }$E_{i t}-d S E_{i t}$ & 2015 & 0,464 & 0,304 & 0,229 & 0,223 \\
\hline
\end{tabular}

$d S E_{i t}, d S_{i}$ - change of the synthetic measure.

Source: own study based on CSO BDL data.

\section{Summary}

The assessment of the competitiveness of local government units and information needs should take into account social and economic characteristics shaping the potential of the region. Internaldifferentiation in the context of the competitiveness of municipalitiesis a naturalphenomenon.

However, it should be remembered that these disproportions must reach a level that is acceptable in a given economic and social situation.

The method used in the article allows for the comparison of the competitiveness of one unit with the other. The value of the measure depends on the number and type of adopted variables to be tested. It can be used by the local government authorities of the region to assess the effectiveness of past development instruments or financial management. It allows to prioritize objects and assess the disproportions between individual cities of the Świętokrzyskie Province.

In the case of low spatial aggregations, we encounter data deficits most often caused by the lack of representativeness of the data resulting from insufficient sample research or simply the lack of research in this field. Therefore, inference should always be cautious and final assessments supported by additional research. 


\section{Bibliography:}

1. Dziekański P. (2012), Informacja jako dobro ekonomiczne będace źródtem przewagi konkurencyjnej, Nierówności Społeczne a Wzrost Gospodarczy, z. nr 24, 387-403.

2. Dziekański P. (2014), Metoda taksonomiczna w ocenie środowiskowej konkurencyjności powiatów województwa świętokrzyskiego, Polityka ekonomiczna, PN UE we Wrocławiu, 348, s. 44-53.

3. Dziekański P. (2015), Wykorzystanie wskaźnika syntetycznego do oceny poziomu rozwoju samorzadu na przyktadzie gmin wiejskich województwa świętokrzyskiego, s. 261-279 [w:] S. Owsiak (red.), Determinanty rozwoju Polski. Finansepubliczne, PTE. Warszawa.

4. Dziekański P. (2016), Spatial Differentiation of the Financial Condition of the Świętokrzyskie Voivodship Counties, BarometrRegionalny, Tom 14 nr 3. s. 79-91.

5. Filipiak B. (2006), Analiza finansowa i jej znaczenie w zarządzaniu finansami [w:] Dylewski M., Filipiak B.,

Gorzalczyńska-Koczkodaj M., Finanse samorzadowe. Narzędzia, decyzje, procesy, Wyd. Nauk. PWN. Warszawa, s. $138-143$

6. Frąś J. (2011), Zarzadzanie informacją elementem budowy przewagi konkurencyjnej e-przedsiębiorstwa, Studia i Prace Wydziału Nauk Ekonomicznych i Zarządzania nr 21.

7. Gorzelak G., Płoszaj A., Smętkowski M. (2006), Ocena strategii rozwoju regionu - wykorzystanie modelu czterech kapitałów na przykładzie województwa lubuskiego. Studia Regionalne i Lokalne Nr 3(25): 67-82.

8. Griffin R.W. (2004), Podstawy zarzadzania organizacjami, Wyd. Nauk. PWN, Warszawa.

9. Kisielnicki J., Sroka H. (1999), Systemy informacyjne biznesu, Agencja Wydawnicza PLACET, Warszawa, s. 13

10. Kleer J. (2005), Identyfikacja dóbr wytwarzanych przez sektor publiczny [w:] Sektor publiczny w Polsce i na świecie. Między upadkiem a rozkwitem, Warszawa, s. 9.

11. Krawczyk M. (2011), Problematyka zarzadzania informacja $i$ wiedza w instytucjach sektora publicznego na przyktadzie Urzędu Komunikacji Elektronicznej, Metody Informatyki Stosowanej, nr 3 (23), 141-147.

12. Lewandowski J. (2002), Aspekty humanizacji pracy w przedsiębiorstwie przyszłości (w:) W. Grudzewski, I. Hejduk (red.), Przedsiębiorstwo przyszłości - wizja strategiczna, Difin, Warszawa, s. 142.

13. Materska K. (2004), Pozyskiwanie informacji gospodarczych (w:) Spoleczeństwo informacyjne i jego technologie, red. B. Sosińska-Kalata, K. Materska, W. Gliński, Wyd. SBP, Warszawa, s. 3-11.

14. Mioduchowska-Jaroszewicz E. (2013), Metody i kierunki oceny kondycji finansowej jednostek samorządów terytorialnych, ZN US, nr 786 Finanse, Rynki Finansowe, Ubezpieczenia, nr 64/2, s. 127-140.

15. Nowicka-Skowron M. (2000), Efektywność systemów logistycznych, PWE, Warszawa, s. 63.

16. Oleński J. (1997), Standardy informacyjne w gospodarce, Wyd. UW, Warszawa, s. 14-15

17. Oleński J. (2000), Elementy ekonomiki informacji, Wyd. Katedra Informatyki Gospodarczej i Analiz Ekonomicznych, Uniwersytet Warszawski, Warszawa, s. 21.

18. Pawlik A. (2011), Zróżnicowanie rozwoju społeczno-gospodarczego w województwie świętokrzyskim,

Wiadomości Statystyczne, nr 11, PTS, GUS, Warszawa, s. 60-70.

19. Piecuch T. (2013), Informacja w funkcjonowaniu wspótczesnych przedsiębiorstw, Modern Management Review, vol. XVIII, 20 (4), 161-170.

20. Pomykalski A. (2001), Zarzadzanie innowacjami, PWN, Warszawa-Lódź.

21. Satoła L. (2015), Kondycja finansowa gmin w warunkach zmiennej koniunktury gospodarczej, Journal of Agribusiness and Rural Development, 1(35), s. 115-123.

22. Sekuła P. (2015), Budżet zadaniowy jako skuteczne narzędzie zarządzania w samorzadzie, Prace Naukowe

Uniwersytetu Ekonomicznego We Wrocławiu, 408, s. 229-238.

23. Sobczyk A. (2009), Finansowanie rozwoju gminy z dochodów własnych, Zeszyty Naukowe SGGW, Ekonomika i Organizacja Gospodarki Żywnościowej, 77, s. 137-149.

24. Stoner A. F., Wankel Ch. (1996), Kierowanie, PWE, Warszawa.

25. Tokarski T. (2005), Statystyczna analiza regionalnego zróżnicowania wydajności, zatrudnienia i bezrobocia w Polsce, Wyd. PTE, Warszawa.

26. Trojak M., Tokarski T. red. (2013), Statystyczna analiza przestrzennego zróżnicowania rozwoju ekonomicznego i społecznego Polski, Wyd. UJ, Kraków, 2013.

27. Wais P. (2014), Miasta jako regionalne bieguny wzrostu - studium województwa podkarpackiego z uwzględnieniem perspektywy socjologicznej [w:] Wspótczesne dylematy zarządzania, Krosno: Prace naukowodydaktyczne, 67.

28. Wiatrak A. P. (1997), System przekazywania i wykorzystania informacji w rolnictwie. Informacja rynkowa dla potrzeb doradztwa rolniczego i podejmowania decyzji produkcyjnych rolników, ATR, Bydgoszcz, s. 33-42.

29. Wysocki F., Lira J. (2005), Statystyka opisowa, Wyd. AR, Poznań.

30. Zeliaś A. (2000) Taksonomiczna analiza przestrzennego zróżnicowania poziomu życia w Polsce w ujęciu dynamicznym, Kraków. 